International Journal of Social Science And Human Research

ISSN(print): 2644-0679, ISSN(online): 2644-0695

Volume 05 Issue 02 February 2022

DOI: 10.47191/ijsshr/v5-i2-19, Impact factor-5.586

Page No: 537-542

\title{
Military Campaign Strategy To Keep Indonesian National Air Regional Sovereignty
}

\author{
Enggal Leksono ${ }^{1}$, Agus Sudayra ${ }^{2}$, Afrizal Hendra ${ }^{3}$, Muhammad Nakir $^{4}$, Bastari $^{5}$, \\ IDK Kertawidana ${ }^{6}$, Haposan Simatupang ${ }^{7}$ \\ 1,2,3,4,5,6,7 Military Campaign and Strategy Study Program Faculty of Defense Strategy, Republic Indonesia Defense University \\ Kawasan IPSC Sentul, Sukahati, Kec. Citeureup, Kabupaten Bogor, Jawa Barat 16810
}

\begin{abstract}
There are still a number of issues that hinder the TNI AU from realizing the development of the TNI AU's Electronic Warfare capability, among others, the organization that organizes trade operations in the TNI AU's operational units is still not ideal, there are still limited software that regulates the implementation of TNI commerce operations, not optimal. preparation of human resources in the field of trading operations, the need for electronic warfare equipment with the latest technology in all operational units of the Indonesian Air Force, and the lack of availability of supporting infrastructure for trading operations. Efforts to anticipate and deal with threats from weapons systems in the current modern war era and maintain national air sovereignty, it is necessary to formulate appropriate strategies, including realizing the development of the Indonesian Air Force electronic warfare organization through the establishment of an organizational structure for the Indonesian Air Force's operational unit and fulfillment of requirements for validation. perrnika organization, realizing the fulfillment of software needs to support the implementation of electronic warfare of the Indonesian Air Force through revision of operational instructions and technical instructions for operational and maintenance of trading equipment, realizing the readiness of personnel carrying out trade operations through the provision of manning personnel according to organizational needs and organizing education and training, realizing the fulfillment of equipment needs equipment to support the TNI AU's commercial operations through the procurement of new equipment, as well as to fulfill the need for supporting infrastructure for the implementation of Electronic Warfare The Indonesian Air Force through the development of infrastructure for a centralized trading database storage facility.
\end{abstract}

KEYWORDS: Electronic Warfare, Air Campaign, and National Airspace Sovereignty

\section{INTRODUCTION}

International recognition of airspace as part of state sovereignty provides strong legitimacy for Indonesia as a broad country. However, this condition can change when Indonesia is unable to control its aerospace area as a support for the economy and national defense (K. Martono, et al., 2011). Airspace is the air space above the land and waters of a country. The Unitary State of the Republic of Indonesia (NKRI) is an archipelagic country that is geographically located between two continents and two oceans, making Indonesia's territory in a strategic position as a world maritime axis for world trade routes, besides that Indonesia also has three Indonesian Archipelagic Sea Lanes (ALKI). ) as a world transportation route that is passed by ships and international flights.

This condition is an advantage as well as a vulnerability for the security of the Republic of Indonesia due to various interests from outside parties, such as violations of territorial, sea and air territories, the entry of illegal immigrants, drug smuggling, terrorism, and support from countries that have an interest in separatists in Indonesia. In maintaining sovereignty in national airspace, the threats that may be faced are threats from modern war era weapon systems. Modern wars that are happening today are known as asymmetric wars, namely non-military wars carried out between strong countries controlling weak countries by distorting the state system, weakening ideology and destroying food security and energy security which leads to economic control and control of natural resources. http://theglobal-review.com).

In the concept of modern warfare, military operations have relied on the Electro Magnetic Spectrum (EMS). EMS is the entire range of electromagnetic radiation (EM) from gamma rays which have the shortest wavelength/high frequency, to radio waves which have the longest wavelength/low frequency. All devices that use EMS have been used by civil, military and individual organizations for intelligence, communication, PNT (positioning, navigation and timing), sensing, C2 (command and control), attack, data transmission, information storage and processing (Joint Chiefs) purposes. of Staff, 2012).

Seeing the current development of weapon system technology, electronic warfare plays a very important role in every military operation, whether on land, at sea or in the air. Peperangan elektronika is a military action using electromagnetic energy to 


\section{Military Campaign Strategy To Keep Indonesian National Air Regional Sovereignty}

determine, utilize and reduce/prevent the use of the opposing electro-magnetic spectrum as well as actions to ensure the effectiveness of the use of the electromagnetic spectrum by the parties themselves (Kep. Kasau no Kep/936/XII/2016. 2016) .

Therefore, the Indonesian Air Force as part of the Indonesian National Armed Forces (TNI) which carries out the duties of the Air Force in the field of defense, with a weapon system that utilizes a lot of electromagnetic wave spectrum, must have optimal communication capabilities to anticipate and deal with threats from the system. modern war era weapons today.

The term electronic warfare refers to military action involving electromagnetic energy and energy directed at controlling the electromagnetic spectrum or attacking the enemy, so that the EW consists of three divisions, namely electronic warfare support (ES), electronic protection (EP). electronics and electronic attack (EA) / electronic attack (Joint Chiefs of Staff, 2012).

From this fact, EW can be a countermesures of weapon systems that use the electro-magnetic spectrum. If we look at the use of drones that have entered the military force in the regional area, such as Singapore, Malaysia, China and Australia which have UCAV (Unmanned Combat Aerial Vehicle) drones, even Australia has officially operated a squadron of aircraft in the form of E/A aircraft. -18 Growlers stationed at RAAF Base Amberly. The EA-18G Growler is an unmanned jet type aircraft that has an electronic air attack (AEA) capability. The Growler has a radio frequency jamming podsse system that allows it to interfere with enemy electronic systems, and is able to provide electronic intelligence, surveillance and reconnaissance data to other aircraft, this aircraft is a support aircraft for the capabilities of the F/A-18 F Super Hornet and F-35A Joint Strike Fighter (CNN Indonesia, 2021).

In addition to weapons systems from drones, MANPADs (Man-Air Defense system) are also weapons systems that use a control system using electromagnetic waves, namely infra-red seeker. The Manpads weapon is a surface-to-air missile that can be used by individuals, so this missile can be owned by Indonesian separatist and terrorist groups that can threaten the safety of lowflying Indonesian Air Force planes in conflict areas in Indonesia.

Regarding the threat phenomenon from the weapon system, the Indonesian Air Force must be able to carry out electronic warfare operations optimally following the current technological capabilities of the weapon system. However, in general, there are still five main issues that hinder the Indonesian Air Force from realizing the development of the Indonesian Air Force's Electronic Warfare capability.

The first problem is that it is still not ideal for the organization to carry out trade operations in the operational units of the Indonesian Air Force. This factor will have an impact on the implementation of the trade-offs that cannot be carried out optimally by the operational unit that is supposed to carry out the trade-offs. This can be seen from the organizational structure/position in the operational unit, namely there is no position of the structure for implementing electronic warfare operations, starting from the Air Squadron level to the Air Force Base and Korpaskhas ranks. Meanwhile, all of these units manned defense equipment equipped with an electronic warfare system.

The second problem is that there are still software limitations that regulate the operation of the TNI-AU's trade unions. This condition has resulted in the absence of the concept of the Indonesian Air Force's electronic warfare operations which is required to run systematically for the purpose of supporting the success of the Air Force's air operations. The third problem is the not yet optimal preparation of human resources in the field of electronic warfare operations. This condition will result in the non-optimal operation of electronic warfare equipment and the operation of electronic warfare equipment, including the maintenance of electronic warfare equipment in order to ensure the readiness of the electronic warfare equipment owned by the unit. The fourth problem is the need for electronic warfare equipment with the latest technology in all operational units of the Indonesian Air Force. The current limitations of the electronic warfare equipment owned by the Indonesian Air Force will affect the success of the trading operations carried out, and will have an impact on the success of air operations carried out by the Indonesian Air Force. The fifth problem is the unavailability of supporting infrastructure for electronic warfare operations. The unavailability of this electronic warfare infrastructure will have an impact on the sustainability of electronic warfare operations

From the explanation above, in order to answer the challenges faced by the Indonesian Air Force in anticipating the arrival of threats in the national airspace with the use of weapons systems in the current era of modern warfare, it is necessary to develop comprehensive policies, strategies and efforts to improve the TNI's electronic warfare capabilities. Air Force.

Seeing the current development of weapon system technology, electronic warfare plays a very important role in every military operation, whether on land, at sea or in the air. Regarding the threat phenomenon from the weapon system, the Indonesian Air Force must be able to optimally carry out electronic warfare operations following the current technological capabilities of the weapon system. However, in general, there are still problems that prevent the Indonesian Air Force from realizing the development of the Indonesian Air Force's Electronic Warfare capability. Thus, the problems in this research can be formulated as follows: First, how is the development of the Indonesian Air Force's electronic warfare capabilities in anticipating and dealing with threats from modern war era weapon systems; and second, how is the electronic warfare strategy in the air campaign to maintain national air sovereignty.

This study has the following objectives: First, to formulate the Indonesian Air Force's electronic warfare capabilities, so that the current condition of the Indonesian Air Force's electronic warfare capabilities and how to use them in anticipating and dealing with threats from modern war era weapon systems will be known; and second, analyzing the electronic warfare strategy in Air 


\section{Military Campaign Strategy To Keep Indonesian National Air Regional Sovereignty}

Campaigen (air campaign) in order to maintain national air sovereignty, so as to be able to recommend what steps and strategies should be taken by the Indonesian Air Force in making policies for the subsequent procurement of electronic warfare equipment.

\section{THEORY}

\section{Defense Strategy Theory}

According to Craig and Grant (1996) in Taufiqurokhman (2016), strategy is the setting of long-term goals and objectives (targeting and long-term goals) of an organization and the direction of action and allocation of resources needed to achieve the goals and objectives (achieve the goals and objectives). objectives). Meanwhile, Tjiptono (2015) states that the term strategy comes from the Greek, namely strategia which means art or science to become a general. Strategy can also be interpreted as a plan for the distribution and use of military power in the strength of certain areas to achieve goals. Meanwhile, based on the opinion of Pearce II and Robinson (2018), strategy is a large-scale plan, with a future orientation, to interact with competitive conditions to achieve goals.

This is in line with David (2011) quoted by Puji (2015), Strategy is together with long-term goals to be achieved. Strategy is an action potential that requires top management decisions and a large amount of organizational resources. So strategy is an action or activity carried out by a person or company to achieve the goals or objectives that have been set. Meanwhile, Rangkuti (2015) argues that strategy is a comprehensive master plan, which explains how the organization will achieve all the goals that have been set based on the mission that has been set previously.

\section{Electronic Warfare Theory}

In optimizing the Indonesian Air Force's electronic warfare capabilities to deal with the threat of electronic warfare in modern warfare era weapon systems, it must be based on a theory that is synchronized with the laws and regulations that have been set. The theories related to electronic warfare are Electromagnetic Waves.

The main activities of Electronic Warfare have been developed over time to address the opportunities and vulnerabilities inherent in the basic physics of electromagnetic energy. Although the basic physics of electromagnetic energy is constant, the development of technology that utilizes electromagnetic energy continues to develop rapidly, and continues to be a challenge in adapting electronic warfare activities. Based on this, the current main activities of electronic warfare are quoted from Joint Publication 3-51, 2020, Joint Doctrinne for Electronic Warfare.

\section{METHODE}

This study uses the research method used by researchers in this study is a qualitative method. According to Creswell (2016) qualitative research is a type of research that explores and understands meaning in a number of individuals or groups of people originating from social problems. In general, qualitative research can be used for research on people's lives, history, behavior, concepts or phenomena, social problems, and others. One of the reasons why using a qualitative approach is the experience of researchers where this method can find and understand what is hidden behind phenomena that are sometimes difficult to understand.

\section{DISCUSSION}

In the concept of modern warfare, military operations have depended on the electromagnetic spectrum, because it plays a very important role in every military operation, whether operations on land, at sea or in the air. This is important for the TNI as the main component of national defense to be adaptive in dealing with any potential disturbances and obstacles through the development of the Indonesian Air Force's electronic warfare capabilities to anticipate the very rapid development of military technology, especially the threats posed to modern war era weapon systems in the future. The development of the Indonesian Air Force's electronic warfare capabilities cannot be separated from the development of the strategic environment that affects current conditions as well as policies, strategies and efforts to be implemented.

The factors that influence the development of the Indonesian Air Force's electronic warfare capabilities include developments in the global environment, regional environment, national environment as well as opportunities and constraints. With a discussion of the development of this strategic environment, things will be obtained that can be taken into consideration in developing the Indonesian Air Force's electronic warfare capabilities if faced with efforts to deal with modern war era weapons systems in order to maintain national airspace sovereignty.

With the design of policies, strategies and efforts that will be prepared later, it is hoped that it can be the right step in planning and strengthening the optimization of the Indonesian Air Force's electronic warfare capabilities in dealing with modern war era weapons systems in order to maintain national airspace sovereignty.

To be able to realize the optimal conditions for the Indonesian Air Force's electronic warfare capabilities as expected, a policy was formulated, namely: "The realization of the Indonesian Air Force's Electronic Warfare Capabilities through the Development of Electronic Warfare Organizing Organizations, Fulfilling Software Needs, Increasing Preparedness of Implementing Personnel, Fulfilling Electronic Warfare Equipment Needs Supporters and Supporting Facilities to deal with modern war-era weapons systems in order to maintain the sovereignty of the national airspace". 


\section{Military Campaign Strategy To Keep Indonesian National Air Regional Sovereignty}

Furthermore, the above-mentioned policy is translated into several strategies and efforts in order to solve the problem of optimizing the Indonesian Air Force's electronic warfare capabilities to deal with modern war-era weapons systems in order to maintain the sovereignty of the national airspace.

In order to get the concept of the right and appropriate strategy, the author uses a SWOT analysis tool. Based on the results of the SWOT analysis above and combined with the Strategic Planning and Forecasting theory from William Archer and William Overholt as well as the development of the strategic environment, four strategies were set to implement the above policies, including the following:

a. The first strategy is to realize the development of the Indonesian Air Force's electronic warfare organization through the establishment of an electronic warfare organization structure in the Indonesian Air Force's operational units; fulfillment of the need for validation of the logic organization with the methods of identification, study, evaluation, coordination, proposal, discussion, testing, determination, development and validation using the means of the TNI Commander Regulation, Rule of Rulers and Orders in order to achieve the goal of realizing the pattern of developing electronic warfare organization organizations Indonesian Air Force.

b. The second strategy is to fulfill the need for software to support the implementation of the Indonesian Air Force's electronic warfare through the revision of operational instructions and technical instructions for the operation and maintenance of electronic warfare equipment; software productivity; socialization of electronic warfare operational software revisions with methods of study, evaluation, coordination, discussion, revision, preparation, proposal, publication, determination, ratification, instruction, production, socialization using the Rules of Rules and Orders in order to achieve the goal of realizing the fulfillment of needs software to support the implementation of the Indonesian Air Force's electronic warfare.

c. The third strategy is to realize the readiness of personnel implementing electronic warfare operations through the provision of manning personnel according to the needs of the organization; providing education and training; improving the welfare of personnel by means of evaluation, coordination, instruction, preparation, determination, socialization, recruitment, coaching, research and development, education and training and cooperation using the means of the TNI Commander Regulation, Rules of Rulers, Decisions of Heads of Heads, Cooperation Agreements, Orders in the framework of achieve the goal of realizing the fulfillment of the readiness of personnel implementing electronic warfare operations.

d. The fourth strategy is to fulfill the need for electronic warfare equipment to support the Indonesian Air Force's electronic warfare operations through the procurement of new electronic warfare equipment; implementation of reconditioning of electronic warfare capabilities; increasing the budget for modernization of defense equipment using the methods of procurement, reconditioning, modernization, evaluation, cooperation and development, using the means of Regulation of the Minister of Defense, Regulation of the Commander of the Armed Forces, Rule of Rulers, Orders and Cooperation Agreements in order to achieve the goal of realizing the fulfillment of the need for electronic warfare equipment to support operations Indonesian Air Force electronic warfare.

e. The fifth strategy is to fulfill the need for supporting infrastructure for the implementation of the Indonesian Air Force's Electronic Warfare through the construction of a centralized electronic warfare database storage facility infrastructure; empowerment of the defense industry with cooperation and development methods, using the means of Regulation of the Minister of Defense, Regulation of the Commander of the TNI, Rule of Rulers, Orders and Cooperation Agreements in order to achieve the goal of realizing the fulfillment of the need for electronic warfare equipment to support the Indonesian Air Force's electronic warfare operations.

\section{CONCLUTION}

Based on the results of the discussion, several conclusions were obtained, namely as follows:

In accordance with the SWOT analysis above and combined with the Strategic Planning and Forecasting theory from William Archer and William Overholt as well as the development of the strategic environment, five strategies were set to implement the above policies, namely as follows: electronic warfare organization in the Indonesian Air Force's operational unit; fulfillment of the need for validation of the graphic organization; second, realizing the fulfillment of the need for software to support the implementation of the Indonesian Air Force's electronic warfare through the revision of the operational instructions and technical instructions for the maintenance of electronic warfare equipment; third, realizing the readiness of personnel implementing electronic warfare operations through the provision of manning personnel according to the needs of the organization; providing education and training; and fourth, realizing the fulfillment of the need for electronic warfare equipment to support the Indonesian Air Force's electronic warfare operations through the procurement of new electronic warfare equipment; and fifth, realizing the fulfillment of the need for supporting infrastructure for the implementation of the Indonesian Air Force's Electronic Warfare through the construction of a centralized electronic warfare database storage facility infrastructure. 


\section{REFERENCES}

1) CNN Indonesia, Mengenal Jet TempurTanpaAwak Milik AS Boeing Growler, diakses pada 8 Maret 2021 diambil dari https://www.cnnindonesia.com/teknologi/20200205181325-199-471985/mengenal-jet-tempur-tanpa-awak-milik-asboeing-growler.

2) Dipua, A., Harahap, N., Puspitawati, D., Aminuddin, F., Prakoso, L. Y., Brawijaya, U., \& Pertahanan, U. (2021). Sea Defense Strategy the Indonesian Navy in Dealing with the South China Sea Conflict. ITALIENISCH, 11(2), 120-126. https://doi.org/https://doi.org/10.1115/italienisch.v11i2.103

3) Doktrin TNI Angkatan Udara SwaBhuwanaPaksaNomorKep/545/V/2019, Pasal 17 Kemampuan TNI AU.

4) Doktrin TNI TridekNomorKep/555/VI/2018, Bab III Ancaman dan GangguanPasal 16.

5) Doktrin TNI TridekNomorKep/555/VI/2018, Bab III Pasal 17.

6) Elan Djaelani dan Rustamaji, (2010) Pengenalan Peperangan Elektronika (Electronic Warfare), Bandung. Pusat Penelitian Informatika, LIPI.

7) Finahliyah Hasan (2016).AnalisisKebijakan Pre-Emptive Self defence George W Bush Jr Terhadap Afghanistan, Universitas Hasanudin, Desember 2016, hal 97.

8) Hasyim, L. O. M., Prakoso, L. Y., Risman, H., La Ode, M. H., Prakoso, L. Y., \& Risman, H. (2021). Perang Semesta (Total War) Strategy for Preventing Terrorism Act (Study in Sultan Hasanuddin International Airport). Sciences, 4(2), 76-86. https://doi.org/10.31014/aior.1991.04.02.277

9) Hermawan, T., Prakoso, L. Y., Sianturi, D., Pertahanan, S., Fakultas, L., Pertahanan, S., \& Pertahanan, U. (20210). INDONESIA' S SEA DEFENSE STRATEGY IN IMPACT ANALYSIS AND THE GOVERNMENT' S EFFORT TO SECURE. Jurnal Strategi Pertahanan Laut, 6(3), 273-296. http://139.255.245.7/index.php/SPL/article/view/641/603

10) Iin Tri Rahayu, Tristiadi Ardi Ardani (2017). Observasi dan wawancara. Malang. Banyumedia

11) JA Pearce, RB Robinson (2018). Manajemen Strategik: Formulasi, Implementasi, dan Pengendalian. Jakarta. Salemba Empat.

12) Joint Publication 3-51, (2020). Joint Doctrine for Electronic Warfar,Hal I-5 to I-8

13) Junaidi, M. E., Prakoso, L. Y., Eka, M., \& Yudho, L. (2021). Pancasila as the Basis for Indonesia's Universal Defense. Journal of Social and Political Sciences, 4(2), 148-154. https://doi.org/10.31014/aior.1991.04.02.283

14) K. Martono, dkk, (2011). Pembajakan, Angkutan dan KeselamatanPenerbangan, Jakarta: Gramata, , h. 158. https://theglobal-review.com/mengenal-perang-asimetris-sifat-bentuk-pola-dan-sumber/

15) Kasih Prihantoro Zakariya, Lukman Yudho Prakoso, Ratna Damayanti, A. D. (2019). Public Policy Analysis of Defense Areas and Defense Area Plan in Grati Pasuruan. The 3th Indonesia International Defense Sciense Seminar, 2(Universitas Pertahanan), 483-490.

16) Kementrian Pertahanan Republik Indonesia, 2015. Buku Putih Pertahanan Indonesia.

17) Kep. Kasau no Kep/936/XII/2016. 2016. Juknis TNI AU tentang Ops Peperangan elektronika

18) Kusuma, A. W., Prakoso, L. Y., Sianturi, D., Pertahanan, S., Fakultas, L., Pertahanan, S., \& Pertahanan, U. (2021). Relevansi Strategi Pertahanan Laut Berdasarkan Doktrin Jalesveva Jayamahe Terhadap Globalisasi Dan Perkembangan Lingkungan Strategis. Strategi Pertahanan Laut, 6(1), 77-100.

19) La Ode, M. H., Prakoso, L. Y., \& Risman, H. (2021). PERANG SEMESTA MELALUI OPTIMALISASI PENERAPAN NILAI PANCASILA PERSATUAN INDONESIA DALAM MENDUKUNG PERTAHANAN NEGARA. Strategi Perang Semesta, 7(1).

20) Lebo, D., Midhio, I. W., \& Prakoso, L. Y. (2021). Comparison of The Indonesia Guerrilla War In The Perspective of The Universal War. Journal Of Sosiasl Sciense, 2.https://doi.org/https://jsss.co.id/index.php/jsss/article/view/122

21) Listiyono, Y., Prakoso, L. Y., \& Sianturi, D. (2021). Strategi Pertahanan Laut dalam Pengamanan Alur Laut Kepulauan Indonesia untuk Mewujudkan Keamanan Maritim dan Mempertahankan Kedaulatan Indonesia. Strategi Pertahanan Laut, 5(3), 103-116.

22) Lukman Yudho Prakoso 1 Gerald Theodorus L. Toruan 3, Dohar Sianturi 4, and Ratna Damayanti 5, S. 2. (2019). Defence State Model for Facing Threats of Radicalism and Terrorism in Indonesian Higher Education-. The 3th Indonesia International Defense Sciense Seminar, 2(BELA NEGARA).

23) Madrohim, M., Prakoso, L. Y., \& Risman, H. (2021). Journal of Social and Pancasila Revitalization Strategy in the Era of. Journal of Social and Political Sciences, Vol.4 No.2 (2021), 4(2), 155-164. https://doi.org/10.31014/aior.1991.04.02.284

24) Moeliono, Lexy J (2016). Analisis Fungsi Subjek dan Objek Sebuah Tujuan. Bandung. ITB Bandung.

25) Moleong, L.J, (2017). Metodologi Penelitian Kualitatif. Bandung. Remaja Rosda Karya.

26) Muhammad Risahdi 1 Mansyur 3 , Andi Henny 4, Lukman Yudho Prakoso 5 and Ratna Damayanti 6, M. J. 2. (2019). The Implementation of Policies to Protect National Vital Objects in the Indonesian Navy's Second Fleet Base SurabayaIIDSS2019. The 3th Indonesia International Defense Sciense Seminar, 2(Obyek Vital Strategis), 506-512. 
27) Mulyadi, M., Prakoso, L. Y., Mudhio, I. W., \& Mulyadi, Lukman Yudho Prakoso, I. W. M. (2021). KONFRONTASI MILITER PEMBEBASAN PAPUA BARAT DALAM PERSPEKTIF STRATEGI PERANG SEMESTA. Jurnal Inovasi Penelitian, 2(1), 265-276. https://doi.org/10.47492/jip.v2i1.635

28) Narindra, K. S., Sudibyo, S., \& Prakoso, L. Y. (2021). OPTIMIZATION OF THE DIPLOMATIC STRATEGY THROUGH CROSS CULTURAL UNDERSTANDING FOR THE GARUDA CONTINGENT IN NAQOURA SOUTH LEBANON. MEDIA BINA ILMIAH, 16(2), 6363-6368.

29) Nasution.S (2015). Metode research : metode penelitian. Jakarta. Bumi Aksara.

30) Nizar, A. A., Pramono, B., Gunawan, R., \& Prakoso, L. Y. (2021). Handling Social Conflicts in the Context of A Military Campaign Strategy (Study in The Working Area of The Balik Papan Police Resort). International Journal of Social Science and Human Research, 04(05), 1205-1209.

https://doi.org/10.47191/ijsshr/v4-i5-40

31) Peraturan Menteri Pertahanan RI Nomor 38 Tahun 2015 Tanggal 31 Desember 2015 tentang Doktrin Pertahanan Negara. Hlm. 16.

32) Prakoso, L. Y., Suhirwan, Sianturi, D., Adriyanto, A., \& Damayanti, R. (2019). Implementasi kebijakan Pokok-Pokok Penyelenggaraan Tugas Bantuan Tentara Nasional Indonesia dalam Menanggulangi Bencana Alam. Proceeding ICDM 2019 Volume 2, 2(kebencanaan).

33) Pramono, B., \& Prakoso, L. Y. (2021). Political Policy for the Papuan Issue in the Context of National Defense. ITALENISCH, 11(2), 271-275. http://italienisch.nl/index.php/VerlagSauerlander/article/view/118

34) Prihantoro, K., Suhirwan, A. I. S., Pramono, B., Saputro, G. E., \& Rianto, L. Y. (n.d.). Tourism Village Government Program, Characterized By State Defense as the Economic Foundation of National Defense.

35) Puji, Rahayu Suci. (2015). Esensi Manajemen Strategi. Sidoarjo. Zifatama Publisher.

36) Rangkuti, Freddy (2015). Teknik Membedah Kasus Bisnis Analisis SWOT Cara Perhitungan Bobot, Rating dan OCAI. Jakarta. Gramedia Pustaka.

37) Robertus Heru Triharjanto, Luqman Faturrohim, Ridanto Eko Poetro, dan Hari Muhammad. (2016). Desain Awal Sistem Satelit Telekomunikasi Pertahanan Indonesia (Preliminary Design Of Indonesian Military Telecomunication Satellite). Bandung. Pusat Teknologi Satelit Lembaga Penerbangan dan Antariksa Nasional

38) Sayidiman Suryohadiprojo (2015). Si Vis Pacem Para Bellum: Membangun Pertahanan Negara Yang Modern Dan Efektif. Jakarta. Gramedia Pustaka Utama.

39) Sugiyono, (2017). Metode Penelitian Kuantitatif, Kualitatif, dan R \& D. Bandung. Alfabeta.

40) Sugiyono, (2018). Metode Penelitian Manajemen Pendekatan : Kuantitatif, Kualitatif, Mixed Methods, Action Research, dan Penelitian valuasi. Bandung. Alfabeta.

41) Suhirwan LY, P., Suhirwan, \& Prakoso, L. Y. (2019). Defense strategy at sea handling of Transnational Organized Crime (TNOC) in Nunukan Indonesia's national sea border. IOP Conference Series: Earth and Environmental Science, 339(1), 12043. https://doi.org/10.1088/1755-1315/339/1/012043

42) Supartono. (2017). Sistem Informasi TNI Dalam Rangka Interoperability Data Link Pertahanan Negara. Jakarta. Badan Penelitian dan Pengembangan Sdm-Kementrian Komuniukasi dan Informasi.

43) Syamsir, dkk. (2017). Pendidikan Pncasila untuk Perguruan Tinggi. Palembang.Badan Kerjasama Perhuruan Tinggi Negeri Wilayah Indonesia Bagian Barat.

44) Taufqurokhman. (2016). Manajemen Strategik. Jakarta. Badan Penerbit Fakultas Ilmu Sosial dan Ilmu Politik Universitas Prof. Dr. Moestopo Beragama.

45) Taylor et. al, (2016). Introduction to Qualitative Research Methods. New Jersey. Wiley \& Sons.

46) Tjiptono, Fandy. (2015). Strategi Pemasaran. Edisi 4. Yogyakarta: Andi. Offset.

47) Undang-Undang Nomor 3 Tahun 2002 tentangPertahanan negara.

48) Undang-Undang RI Nomor 34 Tahun 2004 tentang TNI.

49) Wijaya Hengki. (2018). Analisis Kualitatif Model Spradley (Etnografi). Researchgate.net/publication.

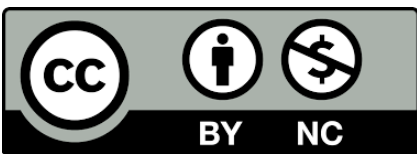

There is an Open Access article, distributed under the term of the Creative Commons Attribution - Non Commercial 4.0 International (CC BY-NC 4.0)

(https://creativecommons.org/licenses/by-nc/4.0/), which permits remixing, adapting and building upon the work for non-commercial use, provided the original work is properly cited. 